\title{
Investigating the role of signaling pathways and cancer stem cells in esophageal cancer with a therapeutic approach Nafise Etaatifard ${ }^{1}$, Nastaran Sahraei ${ }^{1}$, Mehdi Ahmadifar ${ }^{1,2^{*}}$
}

1. Department of biology, college of science, University of science and culture, ACECR, Tehran branch, Iran

2. Department of Stem Cells and Developmental Biology, Cell Science Research Center, Royan Institute for Stem Cell Biology and Technology, ACECR, Tehran, Iran

\section{KEYWORDS}

esophageal cancer;

signaling pathway;

cancer stem cell;

Gene expression

Article Info

Received 2020/09/05;

Accepted 2020/10/03;

Published Online 2020

\section{ABSTRACT}

Esophageal cancer (EC) is the sixth main cause of cancer death worldwide. Important genes associated with esophageal cancer include FOXO3, AKT, and GSK3 $\beta$. Excessive FOXO3 expression inhibits the proliferation of cancer cells. The expression of AKT is involved in controlling cell growth in tumors. GSK3 $\beta$ activity is higher in cancer tissues. Given the effective role of cancer stem cells (CSCs) in the initiation and metastasis of cancer, targeting CSCs seems to be a viable option. Various biomarkers such as CD markers are used to separate CSCs from other cells. Another way to separate CSCs is to use serum-free suspension culture. In the canonical Wnt signaling pathway, $\beta$-catenin with the E-cadherin membrane forms a complex that causes cell adhesion. Using the genes, signaling pathways, and inhibitors such as Wnt, Notch, YAP1, and Hedgehog inhibitors involved in this cancer and isolating CSCs can be considered as effective options for therapeutic purposes.

Corresponding Information: Mehdi Ahmadifar, Department of Stem Cells and Developmental Biology, Cell Science Research Center, Royan Institute for Stem Cell Biology and Technology, ACECR, Tehran, Iran, E-mail:

Mehdi_ahmadifar67@yahoo.com

Copyright (C) 2020. This is an open-access article distributed under the terms of the Creative Commons Attribution-noncommercial 4.0 International License which permit copy and redistribute the material just in noncommercial usages, provided the original work is properly cited.

\begin{abstract}
Abbreviations
EC, Esophageal cancer; ESCC, Esophageal Squamous Cell Carcinoma; EAC, Esophageal Adenocarcinoma; CSCs, Cancer Stem Cells; FOXO3, Forkhead Box O3; PTM, Post-Translational Modification; PKB, Protein Kinase B ; ERK, Extracellular Signal-regulated Kinase; SGK , Serum-and Glucocorticoid-inducible Kinase; pAKT, phosphorylated AKT; PI3K, Phosphoinositide 3-Kinase; mTOR, Mammalian Target Of Rapamycin; GSK3 $\beta$, Glycogen Synthase Kinase 3 Beta; STAT3, Signal Transducer and Activator of Transcription-3; LiCl, Lithium Chloride; CEA, Carcinoembryonic Antigen; CD, Cluster of Differentiation; nCRT, Neoadjuvant Chemoradiotherapy; ALDH1, Aldehyde Dehydrogenase 1; ABCG2, ATP-Binding Cassette super-family G member 2; ITGA7, Integrin $\alpha$ 7; EGFR, Epidermal Growth Factor Receptor; HH, Hedgehog; CCRT, Concurrent Chemoradiotherapy, EMT, Epithelial-mesenchymal transition
\end{abstract}

\section{Introduction}

Esophageal cancer $(\mathrm{EC})^{1}$ is currently the 11 th leading cause of cancer and the sixth leading cause of cancer death (1). Symptoms emerge when the tumor spreads in most parts of the esophagus or metastasizes to adjacent nodes through the lymphatic vessels. Also, tumor growth in external tissues can lead to the appearance of

\footnotetext{
${ }^{1}$ Esophageal cancer
}

symptoms (2). Esophageal cancer is divided into two types:
$1-\mathrm{ESCC}^{2}$
2-EAC ${ }^{3}$

\footnotetext{
2 Esophageal squamous cell carcinoma

${ }^{3}$ Esophageal adenocarcinoma
} 
2 Investigating the role of signaling pathways and cancer stem cells in esophageal cancer...

ESCC is caused by abnormal squamous cell epithelium, which usually occurs in the upper esophageal region. In EAC, the squamous epithelium becomes columnar intestinal epithelium and eventually, EAC is formed $(2,3)$. Unfortunately, about $20 \%$ of tumors do not respond to treatment; Therefore, it is necessary to identify cells that have a high potential for metastasis and are resistant to treatment. These group of cells are called cancer stem cells $(\mathrm{CSCs})^{4}$ (4). This article examines the role of CSCs in esophageal cancer, how to identify and isolate them from other cancer cells, signaling pathways and genes associated with esophageal cancer, and how to use them to diagnose and treat disease.

\section{Genes associated with esophageal cancer \\ FOXO3}

Forkhead box O3 (FOXO3) is a member of the FOX family and a forkhead transcription factor. This gene is located on chromosome 6q21 and plays a vital role in regulating a variety of cellular processes by targeting the expression and activity of effective genes. FOXO3 mediates a variety of cellular processes, including apoptosis, proliferation (5), cell cycle sequence (6), DNA damage (7), and tumor formation. It also responds to several cellular stresses, including ultraviolet radiation (8) and oxidative stress $(9,10)$. Evidence suggests that FOXO3 acts as a tumor suppressor in cancer. This gene is often inactivated in cancer cells by mutation or cytoplasmic degradation, and its inactivation is associated with the onset and progression of cancer. Excessive FOXO3 expression inhibits the proliferation and invasion of cancer cells while shutting them down leads to tumor formation (11). This gene is expressed in many organs such as the esophagus, brain, heart, liver, kidneys, stomach, skin, and etc. FOXO family members are generally regulated by the AKT or Pl3K signaling pathway. It has also been shown that FOXO suppresses the progression of some cancers by suppressing the Wnt / $\beta$-catenin signaling pathway. Indirect regulation of FOXO through inhibition of AKT can be effective in the treatment of cancer $(12,13)$. FOXO3 activity can be regulated by a variety of $\mathrm{PTM}^{5} \mathrm{~s}$, including phosphorylation, sterilization, saturation, and methylation $(14,15,16)$. These reversible PTMs alter the location of FOXO3, affect its binding to DNA, and thus alter the pattern of transcription activity of the related genes $(17,18)$. These changes in FOXO3a occur sequentially by different combinations of enzymes and signaling molecules. The non-phosphorylated form of FOXO3 is located in the nucleus and makes the genes that cause cell apoptosis and cessation of the cell cycle to be expressed. The growth factor signaling leads to the

\footnotetext{
${ }^{4}$ Cancer stem cells

${ }^{5}$ Post-translational modifications
}

activation of protein kinases such as $\mathrm{PKB}^{6}, \mathrm{ERK}^{7}$, and $\mathrm{SGK}^{8}$, which cause phosphorylation of FOXO3. The phosphorylated form of FOXO3 is isolated from DNA and binds to proteins 14-3-3, which causes it to leave the nucleus. This process prevents the expression of FOXO3-related genes, resulting in cell survival and proliferation (19) (Fig. 1).
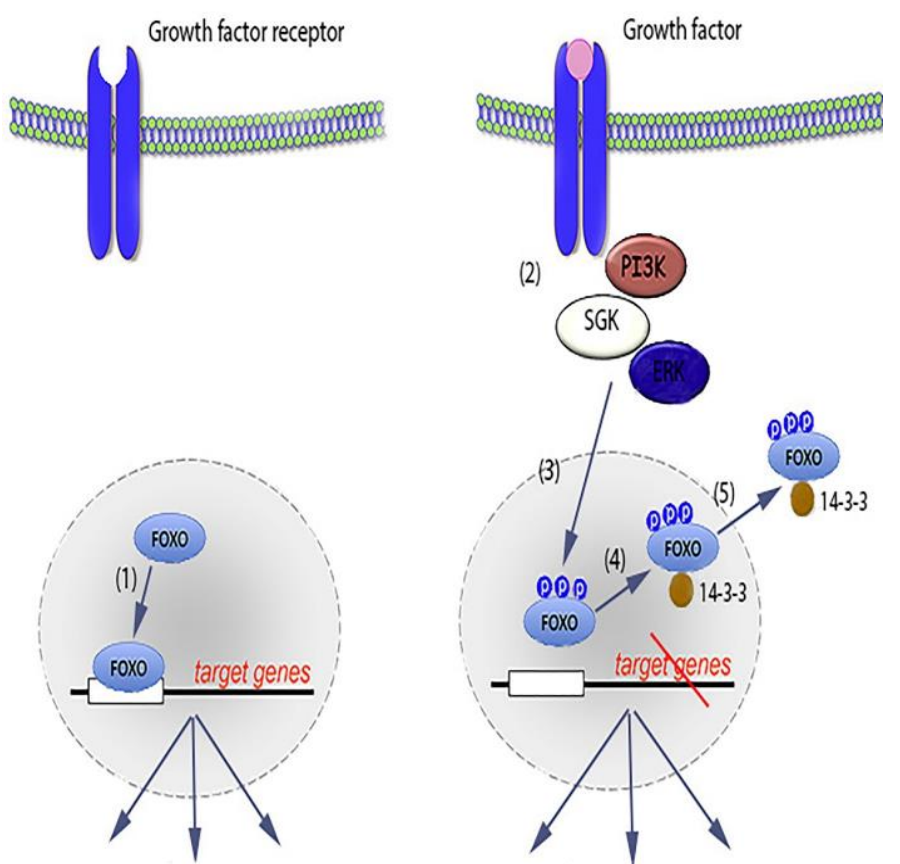

Cell cycle arrest Apoptosis Stress resistance

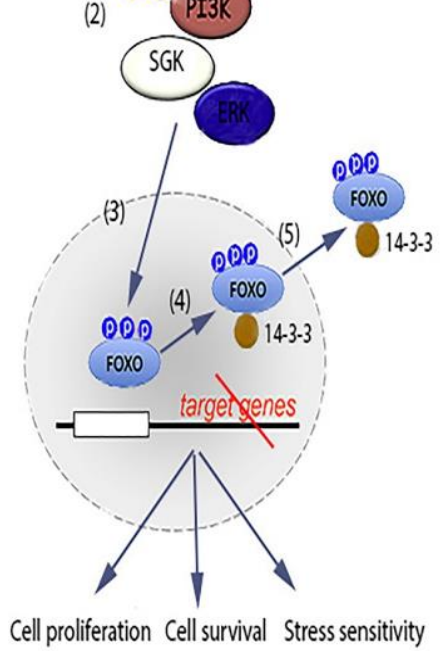

Figure 1. FOXO3 functions in cell mechanism. (1) The binding of the non-phosphorylated form of FOXO3 to DNA and the expression of its target genes cause cell apoptosis, cessation of the cell cycle, and cell resistance to stress. (2) The growth factor signaling leads to the activation of protein kinases such as PKB, ERK and SGK. (3) Phosphorylation of FOXO3 by activated protein kinases. (4) Connecting the phosphorylated form of FOXO3 to protein 14-3-3 and expelling it from the nucleus. As a result, cell survival, cell proliferation, and cell sensitivity to stress occur.

\section{AKT}

Serine/threonine kinase is expressed in many organs, including the esophagus, at a higher rate than FOXO3. The expression or activation of AKT is involved in controlling cell growth, survival, and gene expression in tumors. Inadequate activation of AKT signaling is effective in esophageal cancer. The AKT gene is activated by phosphorylation of $\mathrm{Thr} 308^{9}$ or Ser $473^{10}$.

\footnotetext{
${ }^{6}$ protein kinase $B$

7 extracellular signal-regulated kinase

${ }^{8}$ Serum-and glucocorticoid-inducible kinases

${ }^{9}$ threonine 308

${ }^{10}$ serine 473
} 
pAKT $^{11}$ is involved in apoptosis, cell motility, and destruction (20).AKT Kinase activity is usually regulated in many types of human tumors and can be activated by hormones and some growth factors. Activation of AKT mainly activates the $\mathrm{mTOR}^{12}$ signaling pathways and the GSK3 $\beta$ gene, which ultimately leads to increased proliferation and survival of cancer cells (21). AKT is activated by extracellular stimuli that are $\mathrm{PI} 3 \mathrm{~K}^{13}$-dependent and plays an important role in oncogenesis (22). The AKT Kinase family consists of three isoforms: AKT1, AKT2, and AKT3, which are close to each other and have a high sequence of amino acids $(23,24)$. Activation of AKT Kinase may be associated with increased cell growth and proliferation. AKT also plays a role in resistance to apoptosis through multiple mechanisms (25). Activated AKT phosphorylates several important apoptotic proteins, such as forkhead transcription factors and $\mathrm{KB}$ (NF-KB) nuclear factor (26) (Fig. 2). Activation of AKT plays an important role in protecting cells against apoptosis. Recent laboratory studies have shown that some chemotherapeutic drugs, such as Cisplatin and Doxorubicin, activates AKT in cancer cells by phosphorylation and reduces apoptosis caused by chemotherapy $(27,28)$. AKT is phosphorylated and activated by ionizing radiation, and its activation leads to radioresistance (29). One study found that nc $886^{14}$ inhibited cell proliferation by delaying G1-S transmission, suppressing the AKT pathway, and controlling cell cycle genes. nc886 has low levels of expression in normal cells. When neoplastic cells form and begin to grow in the early stages of carcinogenesis, nc886 expression increases. Shutting down nc886 is a random event that can occur at any time during cancer. When the nc886 shutdown occurs in a neoplastic cell, it activates AKT and promotes G1-S transmission. A study of patients with ESCC found that the nc886 shutdown occurred in a significant proportion of patients, which increased the activity of AKT. Due to the effect of AKT on cell cycle genes, FOXO3 maybe a link between AKT and CDKN1A (30). The results also show that Xanthohumol is an AKT Kinase inhibitor. AKT plays an important role in cell proliferation, survival, and metastasis. The results of an experiment show that pAKT is too expressed in cancerous tissues compared to adjacent tissues, and the removal of AKT1 / 2 in ESCC cells leads to a decrease in colonic formation (31).

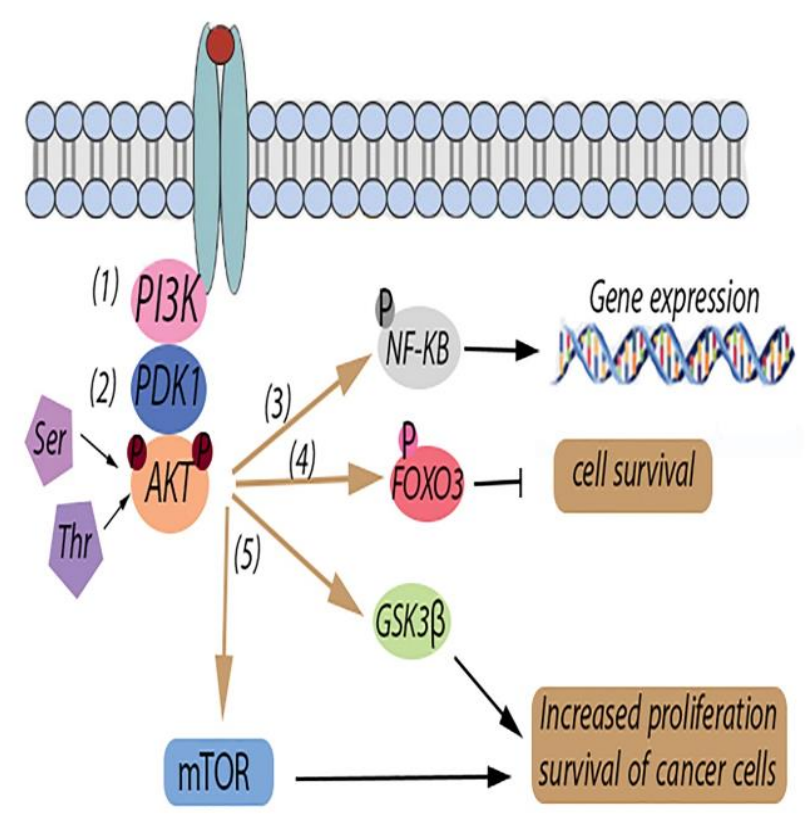

Figure 2. AKT gene functions. (1) Activation of PI3K by binding to receptor (2) AKT phosphorylation by Thr308 and Ser473 and binding to PI3K by PDK1 kinase protein and activation of AKT. (3) NF-KB phosphorylation with active AKT. (4) Phosphorylation of FOXO3 inactivates it and leads to the survival of cancer cells. (5) AKT Activates the GSK3 $\beta$ gene and the mTOR signaling pathway, which increases the proliferation and survival of cancer cells.

\section{$\mathrm{GSK}_{3} \beta$}

One study found that the expression of GSK $3 \beta^{15}$ in cancerous tissues in patients with ESCC is significantly higher than in control tissues, and the amount of phosphorylated GSK3 $\beta$ decreased simultaneously in cancerous tissues. Therefore, inhibition of GSK3 $\beta$ leads to the cessation of cells and ESCC migration. Statistical analysis of clinical data suggests that higher GSK3 $\beta$ expression is associated with a weakening of metastasis and differentiation at a higher rate. GSK3 $\beta$ affects the growth of ESCC by altering STAT ${ }^{16}$ activity (32). The effect of GSK3 $\beta$ on the survival of ESCCs and the progression of cancer leads to greater expression of this gene and low expression of phosphorylated GSK3 $\beta$ in ESCC cancer tissue. Low expression of phosphorylated GSK3 $\beta$ increaseus GSK3 $\beta$ activity. High levels of GSK3 $\beta$ activation increase STAT3 phosphorylation, thereby increasing the survival of cancer cells and the progression of ESCCs. Activation of GSK3 $\beta$ can produce IL-6, thereby facilitating the phosphorylation of STAT3 and thus the growth of ESCC cells. In contrast,

\footnotetext{
${ }^{15}$ Glycogen synthase kinase 3 beta

${ }^{16}$ Signal transducer and activator of transcription-3
} 
4 Investigating the role of signaling pathways and cancer stem cells in esophageal cancer...

the inhibition of GSK3 3 by $\mathrm{LiCl}^{17}$ or SB216763 reduces STAT3 phosphorylation and thus suppresses the growth of cancer cells (32) (Fig. 3). GSK3 $\beta$ reduces the level of free $\beta$-catenin in Wnt / $\beta$-catenin by $\beta$-catenin phosphorylation (33). Since free $\beta$-catenin accumulation has been observed in several cancers, GSK3 $\beta$ is thought to act as a tumor inhibitor by controlling $\beta$-catenin levels $(34,35)$. The expression of circGSK3 $\beta$ inhibits the occurrence of some tumor features such as migration and invasion of cancer cells. This function is largely involved in cancer metastasis. CircGSK3 $\beta$ can reduce $\beta$ catenin levels by inhibiting GSK3 $\beta$. GSK3 $\beta$ is a tumor inhibitor that inhibits cell metastasis through the Wnt / $\beta$-catenin pathway. The GSK3 $\beta$ / $\beta$-catenin pathway plays an important role in the growth and metastasis of tumor cells. The use of circGSK3 $\beta$ in combination with $\mathrm{CEA}^{18}$ can be used as an effective plasma biomarker for $\operatorname{ESCC}(36)$.

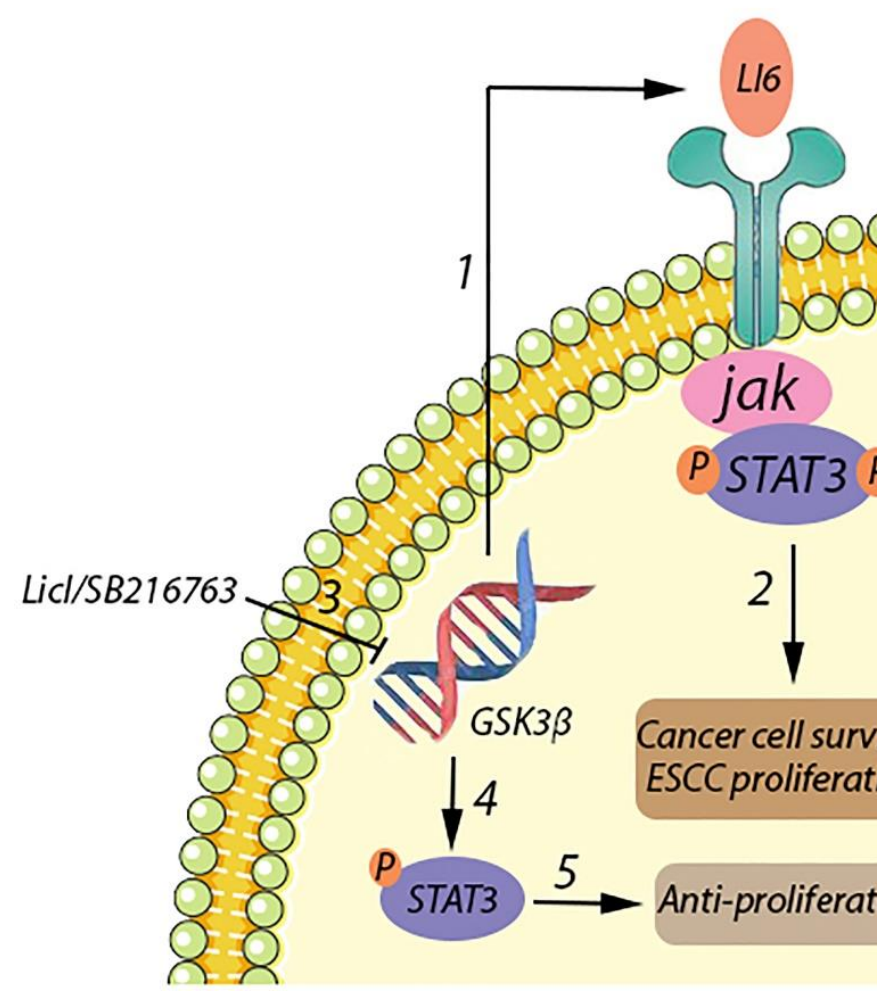

Figure 3. GSK3 $\beta$ gene function (1) Activated GSK3 $\beta$ increases STAT3 phosphorylation. (2) Activation of GSK3 $\beta$ causes IL-6 production, and IL-6 increases STAT3 phosphorylation. As a result, cell survival and increased cancer progression occur in the ESCC. (3) Inhibition of GSK3 $\beta$ by $\mathrm{LiCl} / \mathrm{SB216763,} \mathrm{(4)} \mathrm{reduced}$ STAT3 phosphorylation and thus suppressed cancer cells.

\section{Separation of CSCs from ESCC}

CSCs are a subset of cancer cells that have similar characteristics to embryonic cells; For example, they can multiply and cancer is caused by the activation of cells

${ }^{17}$ lithium chloride

18 carcinoembryonic antigen that are in a state of dormancy (37). Preliminary studies on CSCs showed that only a small percentage of primary tumor cells could produce a secondary tumor. Even if they are in a state of dormancy, CSCs have characteristics opposite to non-CSCs $(39,40)$ and are therefore resistant to treatment in all cases, but when they enter the cell cycle, can recur tumor and metastasis $(40,41,42)$ CSCs are found in a variety of cancers, such as breast cancer (43), prostate cancer (44), and colon cancer $(45,46)$. All CSCs have three features in common: 1 . The ability to reproduce immensely. 2 . The ability to self-renewal 3. Differentiation. ESCC is a malignant tumor of the gastrointestinal tract that can recur and metastasize to nearby lymph nodes (47). Given the effective role that CSCs play in the initiation, proliferation, recurrence, and metastasis of cancer, targeting ESCC cells, especially CSCs, seems to be a viable option. One of the main obstacles in researching CSCs is identifying them. Several methods are currently used to isolate them (48).

\section{Separating CSCs by using biomarkers}

One common way to isolate CSCs from other cells is to use cell surface markers. Types of $\mathrm{CD}^{19}$ markers (CD90, CD44) can be mentioned (49). CD44 is a lymphocyte homing receptor that plays an important role in adhesion, motility, proliferation, and cell survival (50). CD44 performs both as an independent marker and with other markers in CSCs. Different types of CD44 have been suggested as disease prognostic markers in ESCC. CD44 is expressed by most ESCCs in KYSE30 cells (51). Combining CD44 with other markers will further enhance its features (52). A subset of CD44 + / CD24with cancer-like stem cell features is identified in some esophageal cell lines, such as EE33 (EAC), OE21 (ESCC), and esophageal tumor tissue (53). CD24, a cell surface antigen, is involved in cell-matrix and cell interactions $(54,55)$.

CD44 + / CD24- cells have a high potential for spherical mass formation and resistance to radiation. They can also cause high invasive tumors that settle in the hypoxic areas of the tumor. The number of CD $44+$ I $\mathrm{CD} 24$ cells is proportional to the growth rate of the tumor (54). In patients with EAC, CD44 + / CD24 cells are found in $50 \%$ of pre-treatment biopsies, while patients with complete pathological responses after $\mathrm{nCRT}^{20}$ treatment lack these cells (53). These results suggest that CD44 + / CD24- cells have CSCs-like features and can be considered as therapeutic targets (54).

Based on laboratory data, CD44 and ALDH1 $1^{21}$ are used to identify stem cell-like cells in cancer $(56,57)$. The

\footnotetext{
${ }^{19}$ Cluster of differentiation

${ }^{20}$ Neoadjuvant chemoradiotherapy

${ }^{21}$ aldehyde dehydrogenase 1
} 
expression of ALDH1 in ESCC is associated with poor tissue differentiation, lymph node metastasis, and TNM pathological classification $(57,58,59)$. ALDH1 has been overexpressed in various types of CSCs related to breast cancer (60), lung cancer (61) and pancreatic cancer (62), so it can be identified as a marker of CSCs among different types of cancer. Cells with the CD44 + I ICAM1 + (63) marker show phenotypes similar to CSCs. The CD44 + / CD133 + marker also predicts the occurrence or recurrence of ESCC (64). Another cell surface marker that can detect CSCs in esophageal cancer is the $\mathrm{ABCG} 2^{22}$ marker (65). In healthy tissues, the ABCG2 receptor acts as the cell's first line of defense against toxic agents. In the gastrointestinal tract, ABCG2 is widely expressed in the apical membrane of the epithelium (66). High levels of ABCG2 expression in ESCC are associated with TNM classification and lymph node metastasis (67). Therefore, ABCG2 can be considered as a suitable marker for CSCs of esophageal cancer.

Also in esophageal cancer cell lines, cells with the CD90 or Thy-1 marker have the characteristics of resistance to chemotherapy, higher invasiveness, migration, increased potential for spherical mass formation, production of active tumors, and ability to metastasize to the lungs, which are the characteristics of CSCs (68). ITGA7 $7^{23}$, which is involved in regulating cellular matrix interactions and is expressed simultaneously with CD90, has been shown to be a marker of CSCs in esophageal cancer. Excessive ITGA7 expression, along with the transcription factors of Sox2, Nanog, and Oct4, increases self-renewal strength and the ability to differentiate and resist chemotherapy, and therefore ITGA7 can be considered as a marker for CSC (69). $\mathrm{CD} 133^{24}$ is considered as another marker for CSCs that is used either independently (70) or in combination with ABCG2 (71) or CXRC4 (72) to predict disease. By expressing CD27125 in ESCC cells, these cells have characteristics similar to CSCs; For example, the ability to self-regenerate, resistance to chemotherapy, the ability to metastasize (73), and thus can be a predictor marker in ESCC cells (74). Numerous studies have shown that there is a relationship between the presence of $\mathrm{CD}$ groups in the cell and the ability of selfregeneration and multiple differentiation (78-75). Also, by not expressing CD133, the rate of stemness in CSCs decreases (79). Another study, in which ESCC cells with expressed CD90 + were isolated by flow cytometry and whose characteristics were identified by mRNA profiling, showed that the presence of CD90 + is related to tumor growth, Metastasis, and Epithelialmesenchymal transition (EMT)(80). Hedgehog, Notch,
Wnt, PI3K / mTOR, Hippo signaling pathways increase the proliferation, metastasis, invasiveness, and resistance to treatment by regulating CSCs populations(81)(Fig. 4).

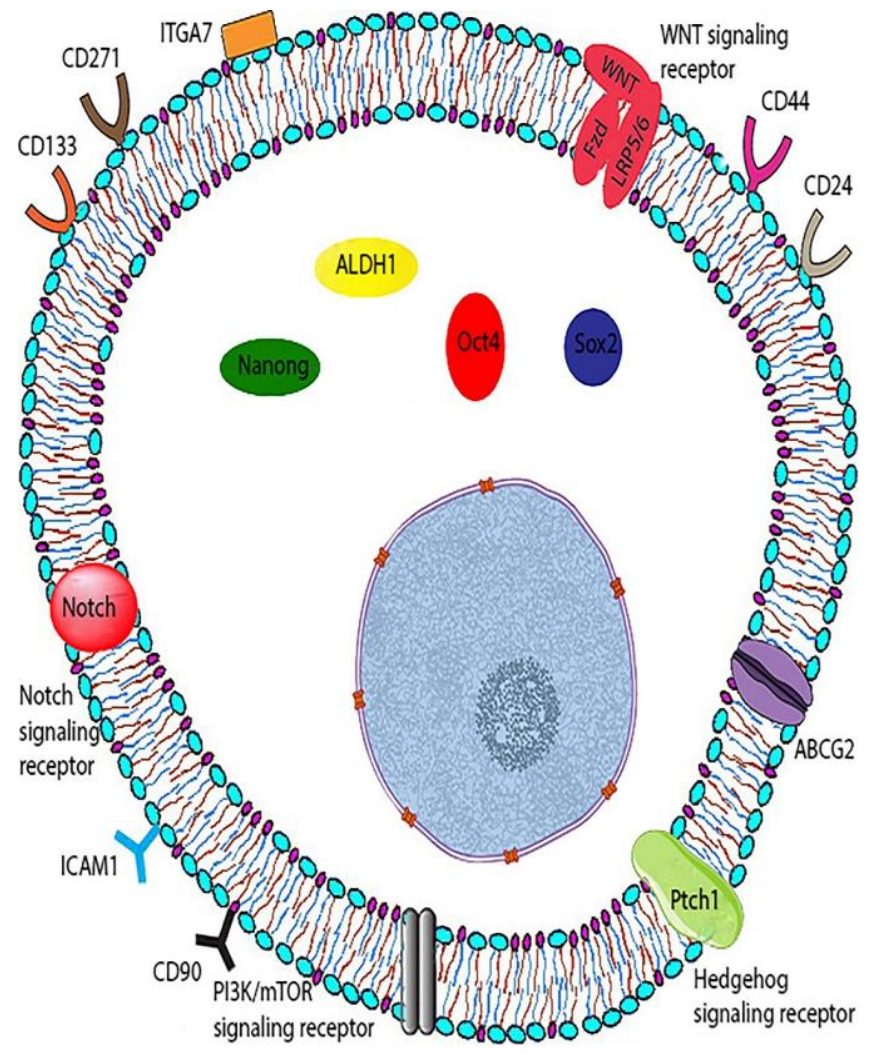

Figure 4. Markers and pathways to identify CSCs. CD90, ITGA7, CD44, ALDH1, CD133, CD24, CD271 markers on cell surface. Presence of Nanog, Sox2, and Oct4 transcription factors to identify CSCs. Hedgehog, Notch, Wnt, PI3K / mTOR and Hippo signaling pathways work to regulate the population of CSCs in the cell.

\section{Serum-free suspension culture}

Another way to separate CSCs from ESCC is to use serum-free suspension culture. In a number of cancers, microspheres of serum suspension have shown similar characteristics to stem cell characteristics $(82,83)$. In a spherical mass, the cells that are closer to the center of the sphere are more differentiated because fewer nutrients reach the center of the spherical mass. The cells in the center, tend to differentiate due to a lack of growth factors (84). The number of CSCs in the spherical mass is constantly increasing, and the cells undergo changes during stages, and the risk of gene mutations increases during the process of cell change. The ability to form spherical masses can indicate the ability of CSCs to self-regenerate (85). Spherical cells isolated from KYSE 150 and TE1 cell lines associated with ESCC are said to be more resistant to radiation therapy than parental cells (86).

\footnotetext{
${ }^{22}$ ATP-binding cassette super-family $\mathrm{G}$ member 2

${ }^{23}$ Integrin $\alpha 7$

${ }^{24}$ prominin-1

${ }^{25}$ p75 neurotropin receptor
} 
6 Investigating the role of signaling pathways and cancer stem cells in esophageal cancer...

\section{Epithelial-mesenchymal transition (EMT)}

As cancer progresses, a fraction of the cancer cells may activate the EMT process to release the primary ${ }^{26}$ cells into different parts of the embryo (87). Cancer cells use this mechanism to invade and expand metastasis (88). The EMT mechanism involves the loss of epithelial properties during the conversion of the mesenchymal spindle-shaped phenotype to higher mobility (89-92). Tumor environmental conditions affected by activation of WNT, TGF- $\beta$, and Hedgehog pathways cause esophageal cancer cells to undergo EMT mechanism, and CSCs features include high invasiveness and metastasis, as well as high survival power. (93-101). Radiation may cause EMT mechanisms by stimulating TGF- $\beta 1$ and HIF- $1 \alpha$ signaling, increasing CD44 expression, and increasing the regulation of transcription factors such as Slug and Snail, as well as reducing PTEN $(102,103)$.

\section{Wnt signaling pathway}

The Wnt signaling pathway plays an important role in cancer biology $(104,105)$. This pathway consists of the canonical Wnt pathway ( $\beta$-catenin-dependent), the bipolar pathways of the cells, and the $\mathrm{Wnt} / \mathrm{Ca}^{2+}(106)$. The canonical Wnt pathway is considered to be a major mechanism in cancer biology (106). Activation of Wnt canonical signaling is a complex multi-step process that exists in Wnt2, GSK3 $\beta$, Axin, APC, $\beta$-catenin, TCF, cmyc, and cyclin D1. Wnt2 in different cells can activate different signaling pathways, including the Wnt2 / $\beta$ catenin pathway, also called the canonical Wnt pathway (107).

The Wnt2 / $\beta$-catenin pathway intensifies the expression of $\beta$-catenin and transfers $\beta$-catenin from the cell membrane to the cytoplasm and even to the nucleus $(105,108)$. $\beta$-catenin is a multipurpose protein that intermediates cellular-matrix adhesion and increases tumor proliferation and metastasis $(109,110)$. $\beta$-catenin plays an important role in tumor progression under the influence of Wnt signaling pathway and E-cadherin $(110,111)$. Wnt 2 signaling pathways can enhance $\beta$ catenin stability and cause free $\beta$-catenin accumulation in the nucleus. GSK3 $\beta$ is one of the few signaling intermediaries that plays a key role in a variety of signaling pathways, including the Wnt signaling pathway. GSK $3 \beta$ can reduce the stability of $\beta$-catenin in the cytoplasm. However, Wnt signaling inhibits GSK3 $\beta$ activity and increases free $\beta$-catenin levels. GSK3 $\beta$ is an essential element in the Wnt signaling pathway and plays an important role in inhibiting $\beta$-catenin, GSK $3 \beta$ has joined the APC, Axin as part of the $\beta$-catenin degradation complex $(112,113)$. The main function of the complex is to destroy $\beta$-catenin phosphorylation. In one study, GSK $3 \beta$ had a positive rate of $7.2 \%$ in ESCC tissues, compared with $54.2 \%$ in normal esophageal tissue. GSK3 $\beta$ is an essential component in the Wnt signaling pathway and plays an important role in regulating cells proliferation, differentiation, and apoptosis (114). However, the expression of GSK3 $\beta$ did not show a significant relationship with tumor size, degree of differentiation, AJCC stage, lymph node status in ESCC. In the normal esophagus, $\beta$-catenin with the Ecadherin membrane forms a complex that causes cell adhesion (Fig. 5). The expression of $\beta$-catenin in the cytoplasm or nucleus can be defined as unconventional expression. Abnormal $\beta$-catenin involves the nucleus to interact with TCF / LEF transcription factors involved in oncogenic development $(115,116)$. The results showed that abnormal $\beta$-catenin expression could be considered as a sign of activation, oncogenesis, Wnt signaling, and $\beta$-catenin / TCF transcription. Phosphorylation is mediated by GSK3 $\beta$ as a switch in $\beta$-catenin stabilization regulation (117). However, the results never indicate a relationship between GSK3 $\beta$ and $\beta$ catenin (118). The $\mathrm{EGFR}^{27}$ receptor is a transmembrane protein composed of an extracellular ligand and a range of intracellular tyrosine kinases. Following ligand binding, EGFR degrades structurally and eventually leads to auto phosphorylation and activation of tyrosine kinase amplitude (119). After that, several paths such as ERK / MAPK, PI3K, and JAK / STAT can be activated to regulate cell proliferation and migration $(12,121)$. The association between EGFR expression and survival rates in patients with ESCC is associated with high levels of EGFR with chemotherapy resistance and lymph node metastasis. Excessive EGFR expression is involved in cell proliferation and higher cell metastasis $(122,123)$. EGFR has been shown to be a direct target of the Wnt pathway, and EGFR activation is associated with increased $\beta$-catenin (124). EGFR activates $\beta$-catenin via PI3K / Akt in tumor cells $(125,126)$. Wnt signaling plays a key role in chromatin regeneration and response to DNA damage (127). Many signaling pathways, such as Wnt, are involved in the regulation of stem cells, and CSCs are no exception (128). Stem cells use their capacity to perform unlimited cells division while maintaining the identity of the stem cells; They are differentiated and created more specialized cells with limited proliferation capacity. Unlimited duplication, self-reconstruction, and multifaceted differentiation are the three major attributes of CSCs $(129,130)$. In unregulated signaling pathways in ESCC, some similar features have been identified with stem cells that act in the same direction as CSCs in ESCC (131). Stem cells are divided into several categories, including embryonic stem cells, totipotent stem cells, and adult stem cells (132). CSCs can also be hierarchically organized. Like natural stem cells, different signaling pathways, such as Wnt, participate in the maintenance and regulation of

${ }^{26}$ primitive

${ }^{27}$ Epidermal growth factor receptor 
CSCs. Because cancer stem cells are unstable, stem cells are abnormally regulated in CSCs. Therefore, stem genes or signaling pathways that are not regulated in CSCs must have two properties: 1) the ability to signal to activate lower currents that help maintain the three main characteristics of stem cells 2) the ability to retain malignant traits $(133,134)$. The Wnt / $\beta$-catenin, Notch, Hedgehog, and Hippo pathways play an important role in the proliferation and self-regeneration of stem cells, are involved in the regulation of EC stem cells, and are considered as potential therapeutic strategies. One experiment showed that Wnt10A, which activates the Wnt / $\beta$-catenin pathway, is present in ESCC tissue and is highly expressed (135).

\section{Result}

The rate of success in the treatment of esophageal cancer is usually measured by the size of the tumor mass and the reduction in metastasis (136). However, CSCs may go through treatment processes without injury and reenter the cells cycle, so CSCs and their characteristics must be considered in treatment strategies (53).

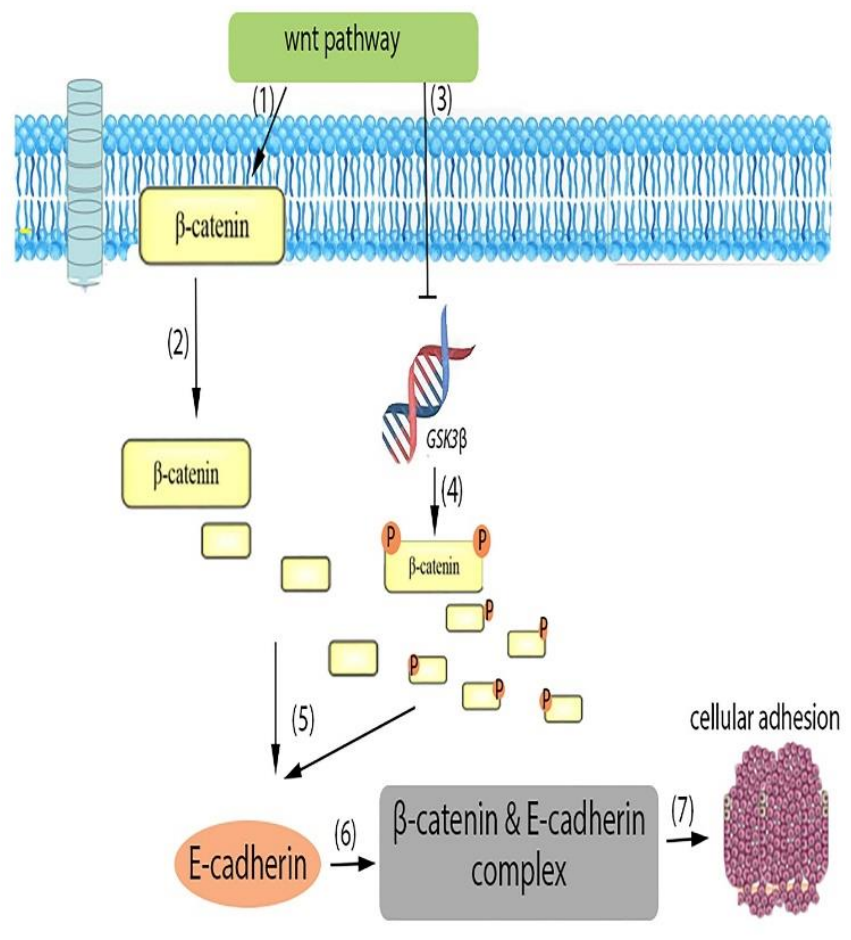

Figure 5. Mechanism and function of Wnt signaling in cancer cells. (1) Wnt signaling increases the expression of $\beta$-catenin. (2) It also causes the transfer of $\beta$-catenin from the cell membrane to the cytoplasm. (3) The Wnt signal inhibits the activity of GSK3 3 , (4) the level of free $\beta$-catenin in cytoplasm increases. (5) The free $\beta$-catenin binds to E-cadherin and (6) the $\beta$-catenin and $E$ cadherin complex is formed. (7) The $\beta$-catenin and $E$ cadherin complex causes cell adhesion and the spread of cancer cells.

\section{$\mathrm{HH}^{28}$ inhibitors}

$\mathrm{HH}$ inhibitors are widely used in clinical trials for various solid tumors. Vismodegib, an inhibitor of Ptch1 and SMO, in combination with chemotherapy do not have favorable results in the treatment of gastrointestinal tumors (137). At present, in a clinical trial, the effect of Vismodegib in combination with nCRT on EAC cells activated by $\mathrm{HH}$ has been investigated. Other SMO inhibitors include sonidegib and taladegib, which are used to treat cancer. Another SMO inhibitor called BMS-833923 is being tested with chemotherapy for the treatment of non-surgical metastatic cancers $(138,139)$.

\section{WNT, Notch, YAP1 inhibitors}

A number of Wnt inhibitors, such as OMP-54F28, PRI724, LGK-974, Vantictumab, are used both independently and in combination with conventional therapies in clinical trials of solid cancers. $\gamma$-secretase inhibitors such as R04929097, LY900009, PF03084014, BMS-906024, BMS-986115, MEDI0639 (anti-DLL4), OMP59R5 (anti-Notch2 / 3), Demcizumab (anti-DLL4) DLL4) and Enoticumab (anti-DLL4) all of which play a role in Notch's signaling, are currently being studied in clinical trials of solid cancers, although none of the above have been used to treat esophageal cancer and are all being studied (138).

\section{Identify new biomarkers to enhance the effectiveness of neoadjuvant chemoradiotherapy}

The most common treatment for operable tumors of any type of esophageal cancer is the use of nCRT therapy, after which surgery can affect more efficiently. Although the survival rate and non-recurrence of the tumor increase after receiving CCRT ${ }^{29}$, some patients do not respond to this treatment (140). About $60 \%$ of patients reportedly did not respond to this treatment, so the success rate in surgery decreased $(141,142)$ Therefore, it is necessary to identify biomarkers that can predict the effectiveness of CCRT in each patient. MiR$330-5 p$ can reduce E2F1 protein and p-Akt cellular levels, thereby increasing apoptosis in cancer cells, and in patients with EAC who do not respond to CCRT therapy, it may decrease. (143). Therefore, detection of miR-221 and increasing its expression in primary tissues of esophageal cancer cells through communication with Wnt / $\beta$-catenin-EMT pathways has been proposed as a solution (144). It is very important to identify biomarkers because they can be used to treat any patients (140).

\section{Conclusion}

Currently, Numerous markers have been studied for the detection of CSCs in esophageal cancer and can be considered as factors in predicting disease, patient

\footnotetext{
${ }^{28}$ Hedgehog

${ }^{29}$ concurrent chemoradiotherapy
} 
8 Investigating the role of signaling pathways and cancer stem cells in esophageal cancer...

response to treatment, or metastasis. These markers, like signaling pathways, can be used to separate CSCs. Despite recent advances, there are still no practical treatments for CSCs. Therefore, identifying and isolating CSCs as a first step in this direction could lead to finding appropriate treatment strategies for each patient in the future.

\section{Acknowledgments}

The authors of this article would like to thank the Royan Institute for their Facilities and resources. 


\section{References}

1. Fitzmaurice C, Allen C, Barber RM, et al. Global Burden of Disease Cancer Collaboration. Global, regional, and national cancer incidence, mortality, years of life lost, years lived with disability, anddisability-adjusted life-years for 32 cancer groups, 1990 to 2015: a systematic analysis for the Global Burden of Disease Study. JAMA Oncol. 1990;2017:524-548.

2. K.J. Napier, M. Scheerer, S. Misra, Esophageal cancer: a review of epidemiology, pathogenesis, staging workup and treatment modalities, World J. Gastrointest.

Oncol. 6 (May (5)) (2014) 112-120.

3. M. Hongo, Y. Nagasaki, T. Shoji, Epidemiology of esophageal cancer: orient to occident. Effects of chronology, geography and ethnicity, J. Gastroenterol. Hepatol. 24 (May (5)) (2009) 729-735.

4. P.P. van Hagen, Preoperative chemoradiotherapy for esophageal or junctional cancer, N. Engl. J. Med. 366 (22) (2012) 2074-2084. 2012-5-31.

5. Descalzo, D. L. M., et al. (2016). "Glucoseinduced oxidative stress reduces proliferation in embryonic stem cells via FOXO3A/ $\beta$-catenindependent transcription of p21cip1." Stem Cell Reports 7(1): 55-68.

6. McGowan, S. E. and D. M. McCoy (2013). "Platelet-derived growth factor-A regulates lung fibroblast S-phase entry through p27 kip1 and FoxO3a." Respiratory research 14(1): 68.

7. Fluteau, A., et al. (2015). "The nuclear retention of transcription factor FOXO3a correlates with a DNA damage response and increased glutamine synthetase expression by astrocytes suggesting a neuroprotective role in the ageing brain." Neuroscience letters 609: 11-17.

8. Wang, X., et al. (2012). "A pathway from JNK through decreased ERK and Akt activities for FOXO3a nuclear translocation in response to UV irradiation." Journal of cellular physiology 227(3): 1168-1178.

9. Lim, S. W., et al. (2017). "Klotho enhances FoxO3-mediated manganese superoxide dismutase expression by negatively regulating PI3K/AKT pathway during tacrolimus-induced oxidative stress." Cell death \& disease $8(8)$ : e2972-e2972.

10. Wang, X., et al. (2017). "Resveratrol ameliorates hyperglycemia-induced renal tubular oxidative stress damage via modulating the SIRT1/FOXO3a pathway." Diabetes research and clinical practice 126: 172-181.

11. Liu, Y., et al. (2018). "Critical role of FOXO3a in carcinogenesis." Molecular cancer 17(1): 104.

12. Zhang W., Duan N., Song T., Li Z., Zhang C., Chen $X$. The emerging roles of forkhead box (FOX) proteins in osteosarcoma. J. Cancer. 2017;8:1619-1628. doi: 10.7150/jca.18778.

13. Guan H., Tan P., Xie L., Mi B., Fang Z., Li J., Yue J., Liao H., Li F. FOXO1 inhibits osteosarcoma oncogenesis via Wnt/beta-catenin pathway suppression. Oncogenesis. 2015;4:e166. doi: 10.1038/oncsis.2015.25.

14. Tikhanovich I, Cox J, Weinman SA. Forkhead box class $\mathrm{O}$ transcription factors in liver function and disease. J Gastroenterol Hepatol. 2013;28(Suppl 1):125-31.

15. Sanphui $\mathrm{P}$, Biswas SC. FoxO3a is activated and executes neuron death via Bim in response to beta-amyloid. Cell Death Dis. 2013;4:e625.

16. Wang $\mathrm{X}, \mathrm{Hu} \mathrm{S}$, Liu L. Phosphorylation and acetylation modifications of FOXO3a: independently or synergistically? Oncol Lett. 2017;13(5):2867-72.

17. Calnan DR, Brunet A. The FoxO code. Oncogene. 2008;27(16):2276-88.

18. Daitoku H, Sakamaki J, Fukamizu A. Regulation of FoxO transcription factors by acetylation and protein-protein interactions. Biochim Biophys Acta. 2011;1813(11):195460.

19. Liu Y, Ao X, Ding W, et al. Critical role of FOXO3a in carcinogenesis. Mol Cancer. 2018;17(1):104. Published 2018 Jul 25. doi:10.1186/s12943-018-0856-3

20. Song, M., et al. (2019). "AKT as a Therapeutic Target for Cancer." Cancer research 79(6): 1019-1031.

21. Wang, Q., et al. (2017). "Akt as a target for cancer therapy: more is not always better (lessons from studies in mice)." British journal of cancer 117(2): 159-163.

22. Franke TF, Kaplan DR and Cantley LC: PI3K: Downstream Akt blocks apoptosis. Cell 88: 435-437, 1997.

23. Murthy SS, Tosolini A, Taguchi $\mathrm{T}$ and Testa JR: Mapping of AKT3, encoding a member of the Akt/protein kinase B family, to human and rodent chromosomes by fluorescence in situ hybridization. Cytogenet Cell Genet 88: 38-40, 2000.

24. Testa JR and Bellacosa A: AKT plays a central role in tumorigenesis. Proc Natl Acad Sci USA 
10 Investigating the role of signaling pathways and cancer stem cells in esophageal cancer...

98: 10983-10985, 2001.

25. Datta SR, Brunet A and Greenberg ME: Cellular survival: a play in three Akts. Genes Dev 13: 2905-2927, 1999.

26. Brunet A, Bonni A, Zigmond MJ, Lin MZ, Juo $\mathrm{P}$, Hu LS, Anderson MJ, Arden KC, Blenis J and Greenberg ME: Akt promotes cell survival by phosphorylating and inhibiting forkhead transcription factor. Cell 96: 857-868, 1999.

27. Yang X, Fraser M, Moll UM, Basak A and Tsang BK: Aktmediated cisplatin resistance in ovarian cancer: Modulation of p53 action on caspase-dependent mitochondrial death pathway. Cancer Res 66: 3126-3136, 2006.

28. Altomare DA, Wang HQ, Skele KL, Rienzo $\mathrm{AD}$, Klein-Szanto, Godwin AK and Testa JR: AKT and mTOR phosphorylation is frequently detected in ovarian cancer and can be targeted to disrupt ovarian tumor cell growth. Oncogene 23: 5853-5857, 2004.

29. Rosenzweig KE, Youmell MB, Palayoor ST and Price BD: Radiosensitization of human tumor cells by the phosphatidylinositol 3-kinase inhibitors wortmannin and LY294002 correlates with inhibition of DNA-dependent protein kinase and prolonged G2-M delay. Clin Cancer Res 61: 3986-3997, 2001.

30. Im, W. R., et al. (2020). "A Regulatory Noncoding RNA, nc886, Suppresses Esophageal Cancer by Inhibiting the AKT Pathway and Cell Cycle Progression." Cells 9(4): 801.

31. Liu, X., et al. (2019). "Targeted therapy of the AKT kinase inhibits esophageal squamous cell carcinoma growth in vitro and in vivo." International journal of cancer 145(4): 10071019.

32. Gao, S., et al. (2017). "Inhibition of glycogen synthase kinase 3 beta (GSK3 $\beta$ ) suppresses the progression of esophageal squamous cell carcinoma by modifying STAT3 activity." Molecular carcinogenesis 56(10): 2301-2316.

33. Behrens J. Control of beta-catenin signaling in tumor development. Ann N Y Acad Sci. 2000;910:21-33. discussion 33-25.

34. Shao J, Teng Y, Padia R, et al. COP1 and GSK3beta cooperate to promote c-Jun degradation and inhibit breast cancer cell tumorigenesis. Neoplasia. 2013;15:1075-1085.

35. Lee CJ, Lee MH, Lee JY, et al. RSK2-induced stress tolerance enhances cell survival signals mediated by inhibition of GSK3beta activity. Biochem Biophys Res Commun.
2013;440:112-118.

36. $\mathrm{Hu}, \mathrm{X}$., et al. (2019). "circGSK3 $\beta$ promotes metastasis in esophageal squamous cell carcinoma by augmenting $\beta$-catenin signaling." Molecular cancer 18(1): 160 .

37. J. Gil, A. Stembalska, K.A. Pesz, M.M. Sasiadek, Cancer stem cells: the theory and perspectives in cancer therapy, J. Appl. Genet. 49 (2) (2008) 193-199.

38. B.J. Huntly, D.G. Gilliland, Leukaemia stem cells and the evolution of cancer-stemcell research, Nat. Rev. Cancer 5 (April (4)) (2005) 311-321.

39. W. Chen, J. Dong, J. Haiech, M.C. Kilhoffer, M. Zeniou, Cancer stem cell quiescence and plasticity as major challenges in cancer therapy, Stem Cells Int. 2016 (2016) 1740936.

40. S. Takeishi, K.I. Nakayama, To wake up cancer stem cells, or to let them sleep, that is the question, Cancer Sci. 107 (July (7)) (2016) 875-881.

41. Z. Yu, T.G. Pestell, M.P. Lisanti, R.G. Pestell, Cancer stem cells, Int. J. Biochem. Cell Biol. 44 (12) (2012) 2144-2151.

42. T. Ishiwata, Cancer stem cells and epithelialmesenchymal transition: novel therapeutic targets for cancer, Pathol. Int. 66 (November (11)) (2016) 601-608.

43. Wright MH, Calcagno AM, Salcido CD, Carlson MD, Ambudkar SV and Lyuba V: Brca1 breast tumors contain distinct CD44+/CD24- and CD133+ cells with cancer stem cell characteristics. Breast Cancer Res 10: R10, 2008.

44. Collins AT, Berry PA, Hyde C, Stower MJ and Maitland NJ: Prospective identification of tumorigenic prostate cancer stem cells. Cancer Res 65: 10946-10951, 2005.

45. Odoux C, Fohrer H, Hoppo T, Guzik L, Stolz DB, Lewis DW, Gollin SM, Gamblin TC, Geller DA and Lagasse E: A stochastic model for cancer stem cell origin in metastatic colon cancer. Cancer Research 68: 6932-6941, 2008.

46. Vermeulen L, Todaro M, de Sousa Mello F, Sprick MR, Kemper K, Perez Alea M, Richel DJ, Stassi G and Medema JP: Single-cell cloning of colon cancer stem cells reveals a multi-lineage differentiation capacity. Proc Natl Acad Sci USA 105: 13427-13432,2008.

47. Ferlay J, Soerjomataram I, Dikshit R, Eser S, Mathers C, Rebelo M, Parkin DM, Forman D and Bray F: Cancer incidence and mortality worldwide: Sources, methods and major 
patterns in GLOBOCAN 2012. Int $\mathrm{J}$ Cancer 136: E359-E386, 2015.

48. Fu W, Lei C, Yu Y, Liu S, Li T, Lin F, Fan X, Shen Y, Ding M, Tang Y, et al: EGFR/Notch antagonists enhance the response to inhibitors of the PI3K-Akt pathway by decreasing tumour-initiating cell frequency. Clin Cancer Res 25: 2835-2847, 2019.

49. Xu PP, Fu D, Li JY, Hu JD, Wang X, Zhou JF, $\mathrm{Yu} \mathrm{H}$, Zhao X, Huang YH, Jiang L, et al: Anthracycline dose optimisation in patients with diffuse large B-cell lymphoma: A multicentre, phase3, randomised, controlled trial. Lancet Haematol 6: e328-e337, 2019.

50. M. Zoller, CD44: can a cancer-initiating cell profit from an abundantly expressed molecule? Nat. Rev. Cancer 11 (April (4)) (2011) 254267.

51. F.B. Rassouli, M.M. Matin, A.R. Bahrami, K. Ghaffarzadegan, H. Cheshomi, S. Lari, et al., Evaluating stem and cancerous biomarkers in CD15+CD44+ KYSE30 cells, Tumour Biol. 34 (October (5)) (2013) 2909-2920.

52. J.K. Smit, H. Faber, M. Niemantsverdriet, M. Baanstra, J. Bussink, H. Hollema, et al., Prediction of response to radiotherapy in the treatment of esophageal cancer using stem cell markers, Radiother. Oncol. 107 (June (3)) (2013) 434-441.

53. Wang, D., et al. (2017). Cancer stem cells with increased metastatic potential as a therapeutic target for esophageal cancer. Seminars in cancer biology, Elsevier.

54. J.K. Smit, H. Faber, M. Niemantsverdriet, M. Baanstra, J. Bussink, H. Hollema, et al., Prediction of response to radiotherapy in the treatment of esophageal cancer using stem cell markers, Radiother. Oncol. 107 (June (3)) (2013) 434-441.

55. H.J. Lee, G. Choe, S. Jheon, S.W. Sung, C.T. Lee, J.H. Chung, CD24, a novel cancer biomarker, predicting disease-free survival of non-small cell lung carcinomas: a retrospective study of prognostic factor analysis from the viewpoint of forthcoming (seventh) new TNM classification, J. Thorac. Oncol. 5 (May (5)) (2010) 649-657.

56. T.N. Almanaa, M.E. Geusz, R.J. Jamasbi, A new method for identifying stem-like cells in esophageal cancer cell lines, J. Cancer 4 (August (7)) (2013) 536-548.

57. Y. Ji, X. Li, Y. Li, Y. Zhong, J. Cao, R. Xu, et al., Aldehyde dehydrogenase-1 expression predicts unfavorable outcomes in patients with esophageal squamous cell carcinoma, Anticancer Res. 36 (January (1)) (2016) 343349.

58. T. Minato, Y. Yamamoto, J. Seike, T. Yoshida, H. Yamai, H. Takechi, et al., Aldehyde dehydrogenase 1 expression is associated with poor prognosis in patients with esophageal squamous cell carcinoma, Ann. Surg. Oncol. 20 (January(1)) (2013) 209-217.

59. K. Shimano, M. Satake, A. Okaya, J. Kitanaka, N. Kitanaka, M. Takemura, et al., Hepatic oval cells have the side population phenotype defined by expression of ATP-binding cassette transporter ABCG2/BCRP1, Am. J. Pathol. 163 (July (1))(2003) 3-9.

60. Moreira MP, da Conceição Braga L and Silva LM: STAT3 as a promising chemoresistance biomarker associated with the CD44+/high/CD24-/low/ALDH+ BCSCs-like subset of the triple-negative breast cancer (TNBC) cell line. Exp Cell Res 363: 283-290, 2018.

61. Macdonagh L, Gallagher MF, Ffrench B, Gasch C, Breen E, Gray SG, Nicholson S, Leonard N, Ryan R, Young V, et al:Targeting the cancer stem cell marker, aldehyde dehydrogenase1, to circumvent cisplatin resistance in NSCLC. Oncotarget 8:72544-72563, 2017.

62. Fu Z, Chen C, Zhou Q, Wang Y, Zhao Y, Zhao $\mathrm{X}$, Li W, Zheng S, Ye H, Wang L, et al: LncRNA HOTTIP modulates cancer stem cell properties in human pancreatic cancer by regulating HOXA9. Cancer Lett 410: 68-81, 2017.

63. S.T. Tsai, P.J. Wang, N.J. Liou, P.S. Lin, C.H. Chen, W.C. Chang, ICAM1 is a potential cancer stem cell marker of esophageal squamous cell carcinoma, PLoS One 10 (November (11)) (2015) e0142834.

64. K. Okamoto, I. Ninomiya, Y. Ohbatake, A. Hirose, T. Tsukada, S. Nakanuma, et al., Expression status of CD44 and CD133 as a prognostic marker in esophageal squamous cell carcinoma treated with neoadjuvant chemotherapy followed by radical esophagectomy, Oncol. Rep. 36 (December (6)) (2016) 3333-3342.

65. X.W. Ding, J.H. Wu, C.P. Jiang, ABCG2: a potential marker of stem cells and novel target in stem cell and cancer therapy, Life Sci. 86 (April (17-18)) (2010)631-637.

66. W. Mo, J.T. Zhang, Human ABCG2: structure, function, and its role in multidrug resistance, Int. J. Biochem. Mol. Biol. 3 (1) (2012) 1-27. 
12 Investigating the role of signaling pathways and cancer stem cells in esophageal cancer...

67. L. Huang, Q. Lu, Y. Han, Z. Li, Z. Zhang, X. $\mathrm{Li}, \mathrm{ABCG} / \mathrm{V}$-ATPase was associated with the drug resistance and tumor metastasis of esophageal squamous cancer cells, Diagn. Pathol. 17 (December (7)) (2012) 180-1596-7180.

68. K.H. Tang, Y.D. Dai, M. Tong, Y.P. Chan, P.S. Kwan, L. Fu, et al., A CD90(+) tumor-initiating cell population with an aggressive signature and metastatic capacity in esophageal cancer, Cancer Res. 73 (April (7)) (2013) 2322-2332.

69. X.Y. Ming, L. Fu, L.Y. Zhang, Y.R. Qin, T.T. Cao, K.W. Chan, et al., Integrin alpha7 is a functional cancer stem cell surface marker in oesophageal squamous cell carcinoma, Nat. Commun. 7 (December (7)) (2016) 13568.

70. Y.P. Sui, X.P. Jian, L.I. Ma, G.Z. Xu, H.W. Liao, Y.P. Liu, et al., Prognostic value of cancer stem cell marker CD133 expression in esophageal carcinoma: a metaanalysis, Mol. Clin. Oncol. 4 (January (1)) (2016) 77-82.

71. D. Hang, H.C. Dong, T. Ning, B. Dong, D.L. Hou, W.G. Xu, Prognostic value of the stem cell markers CD133 and ABCG2 expression in esophageal squamous cell carcinoma, Dis. Esophagus 25 (September-October (7)) (2012) 638-644.

72. C. Lu, F. Xu, J. Gu, Y. Yuan, G. Zhao, X. Yu, et al., Clinical and biological significance of stem-like CD133(+)CXCR4(+) cells in esophageal squamous cell carcinoma, J. Thorac. Cardiovasc. Surg. 150 (August (2)) (2015) 386-395.

73. S.D. Huang, Y. Yuan, X.H. Liu, D.J. Gong, C.G. Bai, F. Wang, et al., Self-renewal and chemotherapy resistance of p75NTR positive cells in esophageal squamous cell carcinomas, BMC Cancer 10 (January (9)) (2009) 9-2407-99.

74. S. Li, D. Yue, X. Chen, L. Wang, J. Li, Y. Ping, et al., Epigenetic regulation of CD271, a potential cancer stem cell marker associated with chemoresistance and metastatic capacity, Oncol. Rep. 33 (January (1)) (2015) 425-432.

75. Jia ZF, Wu YH, Cao DH, Cao XY, Jiang J and Zhou BS: Polymorphisms of cancer stem cell marker gene CD133 are associated with susceptibility and prognosis of gastric cancer. Future Oncol 13: 979-989, 2017.

76. Kalantari E, Asgari M, Nikpanah S, Salarieh N, Lari $\mathrm{MH}$ and Madjd Z: Co-expression of putative cancer stem cell markers CD44 and CD133 in prostate carcinomas. Pathol Oncol Res 23:793-802, 2017.
77. Al-Hajj M, Wicha MS, Benito-Hernandez A, Morrison SJ and Clarke MF: Prospective identification of tumorigenic breast cancer cells. Proc Natl Acad Sci USA 100: 3983-3988, 2003.

78. Yan Y, Zuo X and Wei D: Concise review: Emerging role of CD44 in cancer stem cells: A promising biomarker and therapeutic target. Stem Cells Transl Med 4: 1033-1043, 2015.

79. Liou GY: CD133 as a regulator of cancer metastasis through the cancer stem cells. Int $\mathrm{J}$ Biochem Cell Biol 106: 1-7, 2019.

80. Tang KH, Dai YD, Tong M, Chan YP, Kwan PS, Fu L, Qin YR, Tsao SW, Lung HL, Lung ML, et al: A CD90(+) tumor-initiating cell population with an aggressive signature and metastatic capacity in esophageal cancer. Cancer Res 73: 2322-2332, 2013.

81. A.Long, V. Giroux, K.A. Whelan, K.E. Hamilton, M.P. Tetreault, K. Tanaka, et al., WNT10A promotes an invasive and selfrenewing phenotype in esophageal squamous cell carcinoma, Carcinogenesis 36 (May (5)) (2015) 598-606.

82. Xiao G, Li X, Li G, Zhang B, Xu C, Qin S, Du $\mathrm{N}$, Wang J, Tang SC, Zhang J, et al: MiR-129 blocks estrogen induction of NOTCH signaling activity in breast cancer stem-like cells. Oncotarget 8: 103261-103273, 2017.

83. Trisciuoglio D, Tupone MG, Desideri M, Di Martile M, Gabellini C, Buglioni S, Pallocca $\mathrm{M}$, Alessandrini G, D'Aguanno $\mathrm{S}$ and Del Bufalo D: BCL-XL overexpression promotes tumor progression-associated properties. Cell Death Dis 8: 3216, 2017.

84. Jimenez-Pascual A, Hale JS, Kordowski A, Pugh J, Silver DJ, Bayik D, Roversi G, Alban $\mathrm{TJ}$, Rao S, Chen R, et al: ADAMDEC1 maintains a growth factor signaling loop in cancer stem cells. Cancer Discov: pii: CD-18-1308, 2019.

85. Abbaszadegan MR, Bagheri V, Razavi MS, Momtazi AA, Sahebkar A and Gholamin M: Isolation, identification and characterization of cancer stem cells: A review. J Cell Physiol 232: 2008-2018, 2017.

86. Wang JL, Yu JP, Sun ZQ and Sun SP: Radiobiological characteristics of cancer stem cells from esophageal cancer cell lines. World $\mathbf{J}$ Gastroenterol 20: 18296-18305, 2014.

87. L. Kerosuo, M. Bronner-Fraser, Whatâ $€^{\mathrm{TM}_{\mathrm{S}}}$ bad in cancer is good in the embryo: importance of EMT in neural crest development, Semin. Cell Dev. Biol. 23 (May(3)) (2012) 320-332. 
88. S.S. Wang, J. Jiang, X.H. Liang, Y.L. Tang, Links between cancer stem cells and epithelialmesenchymal transition, OncoTargets Ther. 16 (October (8)) (2015)2973-2980.

89. T. Ishiwata, Cancer stem cells and epithelialmesenchymal transition: novel therapeutic targets for cancer, Pathol. Int. 66 (November (11)) (2016) 601-608.

90. S.S. Wang, J. Jiang, X.H. Liang, Y.L. Tang, Links between cancer stem cells and epithelialmesenchymal transition, OncoTargets Ther. 16 (October (8)) (2015)2973-2980.

91. B. Dave, V. Mittal, N.M. Tan, J.C. Chang, Epithelial-mesenchymal transition, cancer stem cells and treatment resistance, Breast Cancer Res. 14 (January (1))(2012) 202.

92. B. Du, J.S. Shim, Targeting epithelialMesenchymal transition (EMT) to overcome drug resistance in cancer, Molecules 21 (July (7))(2016)http://dx.doi.org/10 . 3390/molecules21070965.

93. H. Gao, C. Teng, W. Huang, J. Peng, C. Wang, SOX2 promotes the epithelial to mesenchymal transition of esophageal squamous cells by modulating slug expression through the activation of STAT3/HIF-alpha signaling, Int. J. Mol. Sci. 16 (September (9)) (2015) 2164321657.

94. N. Isohata, K. Aoyagi, T. Mabuchi, H. Daiko, M. Fukaya, H. Ohta, et al., Hedgehog and epithelial-mesenchymal transition signaling in normal and malignant epithelial cells of the esophagus, Int. J. Cancer 125 (September (5)) (2009) 1212-1221.

95. J. He, M. Zhou, X. Chen, D. Yue, L. Yang, G. Qin, et al., Inhibition of SALL4 reduces tumorigenicity involving epithelialmesenchymal transition via Wnt/beta-catenin pathway in esophageal squamous cell carcinoma, J. Exp. Clin. Cancer Res. 35 (June (1)) (2016) 98-016-0378-z.

96. D. Chen, W. Li, S. Liu, Y. Su, G. Han, C. Xu, et al., Interleukin-23 promotes the epithelialmesenchymal transition of oesophageal carcinoma cells via the Wnt/beta-catenin pathway, Sci. Rep. 27 (February (5)) (2015) 8604.

97. F. Bu, X. Liu, J. Li, S. Chen, X. Tong, C. Ma, et al., TGF-beta1 induces epigenetic silence of TIP30 to promote tumor metastasis in esophageal carcinoma, Oncotarget 6 (February (4)) (2015) 2120-2133.

98. J. Liu, L. Chen, H. Deng, B. Xu, M. Li, X. Zheng, et al., Epithelial-to-mesenchymal transition in human esophageal cancer associates with tumor progression and patient's survival, Int. J. Clin. Exp. Pathol. 7 (September (10)) (2014) 6943-6949.

99. X. Tong, L. Li, X. Li, L. Heng, L. Zhong, X. $\mathrm{Su}$, et al., SOX10, a novel HMG-boxcontaining tumor suppressor, inhibits growth and metastasis of digestive cancers by suppressing the Wnt/beta-catenin pathway, Oncotarget 5 (November (21))(2014) 10571-10583.

100. H.Y. Zhang, Z.Q. Wang, Y.Y. Li, F. Wang, Q.R. Zeng, Y. Gao, et al., Transforming growth factor-beta1-induced epithelial-mesenchymal transition in human esophageal squamous cell carcinoma via the PTEN/PI3K signaling pathway, Oncol. Rep. 32 (Novemebr (5)) (2014) 2134-2142.

101. Y. Niwa, S. Yamada, M. Koike, M. Kanda, T. Fujii, G. Nakayama, et al., Epithelial to mesenchymal transition correlates with tumor budding and predicts prognosis in esophageal squamous cell carcinoma, J. Surg. Oncol. 110 (November (6)) (2014) 764-76

102. A.Kanamoto, I. Ninomiya, S. Harada, T. Tsukada, K. Okamoto, S. Nakanuma, et al., Valproic acid inhibits irradiation-induced epithelial-mesenchymal transition and stem cell-like characteristics in esophageal squamous cell carcinoma, Int. J. Oncol. 49 (November (5)) (2016) 1859-1869.

103. E. He, F. Pan, G. Li, J. Li, Fractionated ionizing radiation promotes epithelialMesenchymal transition in human esophageal cancer cells through PTEN deficiencyMediated akt activation, PLoS One 10 (May (5)) (2015) e0126149.

104. Behrens J, Lustig B. The Wnt connection to tumorigenesis. Int J Dev Biol 2004; 48: 477487.

105. Polakis P. Wnt signaling in cancer. Cold Spring Harb Perspect Biol 2012; 4: a008052.

106. Widelitz R. Wnt signaling through canonical and non-canonical pathways: recent progress. Growth Factors 2005; 23: 111-6.

107. Zhang C, Fu L, Fu J, Hu L, Yang H, Rong TH, Li Y, Liu H, Fu SB, Zeng YX, Guan XY. Fibroblast growth factor receptor 2-positive fibroblasts provide a suitable microenvironment for tumor development and progression in esophageal carcinoma. Clin Cancer Res 2009; 15: 401727.

108. Peifer M, Polakis P. Wnt signaling in oncogenesis and embryogenesis a look outside the nucleus. Science 2000; 287: 1606-1609. 
14 Investigating the role of signaling pathways and cancer stem cells in esophageal cancer...

109. Gkretsi V, Zhang Y, Tu Y, Chen K, Stolz DB, Yang Y, Watkins SC, Wu C. Physical and functional association of migfilin with cell-cell adhesions. J Cell Sci 2005; 118: 697-710.

110. Kudo Y, Kitajima S, Ogawa I, Hiraoka M, Sargolzaei S, Keikhaee MR, Sato S, Miyauchi $\mathrm{M}$, Takata T. Invasion and metastasis of oral cancer cells require methylation of E-cadherin and/or degradation of membranous betacatenin. Clin Cancer Res 2004; 10: 54555463.

111. Polakis P. The oncogenic activation of betacatenin. Curr Opin Genet Dev 1999; 9: 1521.

112. MacDonald BT, Tamai K, He X. Wnt/betacatenin signaling: components, mechanisms, and diseases. Dev Cell 2009; 17: 9-26.

113. Clevers H. Wnt/beta-catenin signaling in development and disease. Cell 2006; 127: 469480.

114. Xu X, Sun PL, Li JZ, Jheon S, Lee CT, Chung $\mathrm{JH}$. Aberrant Wnt $1 / \beta$-catenin expression is an independent poor prognostic marker of nonsmall cell lung cancer after surgery. J Thorac Oncol 2011; 6: 716-724.

115. He H, Ding F, Li Y, Luo A, Chen H, Wu C, Liu Z. Migfilin regulates esophageal cancer cell motility through promoting GSK-3b-mediated degradation of $\beta$-catenin. Mol Cancer Res 2012; 10: 273-81.

116. Nusse R. Wnt Signaling. Cold Spring Harb Perspect Biol 2012; 4: a011163.

117. Ninomiya I, Endo Y, Fushida S, Sasagawa T, Miyashita T, Fujimura T, Nishimura G, Tani T, Hashimoto $\mathrm{T}$, Yagi $\mathrm{M}$, Shimizu $\mathrm{K}$, Ohta T, Yonemura Y, Inoue M, Sasaki T, Miwa K. Alteration of beta-catenin expression in esophageal squamous-cell carcinoma. Int $\mathbf{J}$ Cancer 2000; 85: 757-61.

118. Deng, F., et al. (2015). "Clinicopathological significance of wnt $/ \beta$-catenin signaling pathway in esophageal squamous cell carcinoma." International journal of clinical and experimental pathology 8(3): 3045.

119. Ciardiello F, Tortora G. Epidermal growth factor receptor (EGFR) as a target in cancer therapy: understanding the role of receptor expression and other molecular determinants that could influence the response to anti-EGFR drugs. Eur J Cancer. 2003;39(10):1348-54.

120. Anido J, Matar P, Albanell J, Guzman M, Rojo F, Arribas J, Averbuch S, Baselga J. ZD1839, a specific epidermal growth factor receptor (EGFR) tyrosine kinase inhibitor, induces the formation of inactive EGFR/HER2 and EGFR/HER3 heterodimers and prevents heregulin signaling in HER2-overexpressing breast cancer cells. Clinical cancer research : an official journal of the American Association for Cancer Research. 2003;9(4):1274-83.

121. Normanno N, De Luca A, Bianco C, Strizzi L, Mancino M, Maiello MR, Carotenuto A, De Feo G, Caponigro F, Salomon DS. Epidermal growth factor receptor (EGFR) signaling in cancer. Gene. 2006;366(1):2-16.

122. Wang X, Zhang S, Maclennan GT, Biermann K, Foster RS, Beck SD, Cheng L. Epidermal growth factor receptor protein expression and gene amplification in the chemorefractory metastatic embryonal carcinoma. Modern pathology : an official journal of the United States and Canadian Academy of Pathology, Inc. 2009;22(1):7-12.

123. Wang X, Zhang S, MacLennan GT, Eble JN, Lopez-Beltran A, Yang XJ, Pan CX, Zhou H, Montironi R, Cheng L. Epidermal growth factor receptor protein expression and gene amplification in small cell carcinoma of the urinary bladder. Clinical cancer research : an official journal of the American Association for Cancer Research. 2007;13(3):953-7.

124. Tan X, Apte U, Micsenyi A, Kotsagrelos E, Luo JH, Ranganathan S, Monga DK, Bell A, Michalopoulos GK, Monga SP. Epidermal growth factor receptor: a novel target of the Wnt/beta-catenin pathway in liver. Gastroenterology. 2005;129(1):285-302.

125. Agarwal A, Das K, Lerner N, Sathe S, Cicek M, Casey G, Sizemore N. The AKT/I kappa B kinase pathway promotes angiogenic/metastatic gene expression in colorectal cancer by activating nuclear factor-kappa $\mathrm{B}$ and betacatenin. Oncogene. 2005;24(6):1021-31.

126. Ji H, Wang J, Nika H, Hawke D, Keezer S, Ge Q, Fang B, Fang X, Fang D, Litchfield DW, Aldape K, Lu Z. EGF-induced ERK activation promotes CK2-mediated disassociation of alpha-catenin from beta-catenin and transactivation of betacatenin. Mol Cell. 2009;36(4):547-59.

127. Zhao, Y., et al. (2018). "Wnt signaling induces radioresistance through upregulating HMGB1 in esophageal squamous cell carcinoma." Cell death $\&$ disease 9(4): 1-15.

128. Sharon N, Vanderhooft J, Straubhaar J, Mueller J, Chawla R, Zhou Q, Engquist EN, Trapnell C, Gifford DK and Melton DA: Wnt signaling separates the progenitor and 
endocrine compartments during pancreas development. Cell Rep 27: 2281-2291.e5, 2019.

129. Ma L, Wang Y, Hui Y, Du Y, Chen Z, Feng $\mathrm{H}$, Zhang S, Li N, Song J, Fang Y, et al: WNT/NOTCH pathway is essential for the maintenance and expansion of human MGE progenitors. Stem Cell Reports 12: 934-949, 2019.

130. Huynh DL, Koh H, Chandimali N, Zhang JJ, Kim N, Kang TY, Ghosh M, Gera M, Park YH, Kwon T and Jeong DK: BRM270 inhibits the proliferation of CD44 positive pancreatic ductal adenocarcinoma cells via downregulation of sonic hedgehog signaling. Evid Based Complement Alternat Med 2019: 8620469, 2019.

131. Yue D, Zhang Z, Li J, Chen X, Ping Y, Liu S, Shi X, Li L, Wang L, Huang L, et al: Transforming growth factor-beta1 promotes the migration and invasion of sphere-forming stemlike cell subpopulations in esophageal cancer. Exp Cell Res 336: 141-149, 2015.

132. De Luca M, Aiuti A, Cossu G, Parmar M, Pellegrini G and Robey PG: Advances in stem cell research and therapeutic development. Nat Cell Biol 21: 801-811, 2019.

133. Galoczova M, Coates $\mathrm{P}$ and Vojtesek B: STAT3, stem cells, cancer stem cells and p63. Cell Mol Biol Lett 23: 12, 2018.

134. Wu, Q., et al. (2019). "Cancer stem cells in esophageal squamous cell cancer." Oncology letters 18(5): 5022-5032.

135. Wang, D., et al. (2017). Cancer stem cells with increased metastatic potential as a therapeutic target for esophageal cancer. Seminars in cancer biology, Elsevier.

136. M. Fan, Y. Lin, J. Pan, W. Yan, L. Dai, L. Shen, et al., Survival after neoadjuvant chemotherapy versus neoadjuvant chemoradiotherapy for resectable esophageal carcinoma: a meta-analysis, Thorac. Cancer 7 (March (2)) (2016) 173-181.

137. N. Takebe, L. Miele, P.J. Harris, W. Jeong, H. Bando, M. Kahn, et al., Targeting Notch, Hedgehog, and Wnt pathways in cancer stem cells: clinical update, Nat. Rev. Clin. Oncol. (April) (2015).

138. D.J. Cohen, P.J. Christos, J.A. Sparano, H.L. Kindler, D.V.T. Catenacci, T.B. Bekaij-Saab, S. Tahiri, Y.Y. Janjigian, K.B. Michael, E. Chan, L. Rajdev, S. Urba, J.L. Wade, et al., A randomized phase II study of vismodegib (V), a hedgehog $(\mathrm{HH})$ pathway inhibitor, combined with FOLFOX in patients (pts) with advanced gastric and gastroesophageal junction (GEJ) carcinoma: a New York Cancer Consortium led study (abstract), J. Clin. Oncol. 31 (suppl 4) (2013) (abstr 67).

139. T.K. Rimkus, R.L. Carpenter, S. Qasem, M. Chan, H.W. Lo, Targeting the sonic hedgehog signaling pathway: review of smoothened and GLI inhibitors, Cancers (Basel) 8 (February (2)) (2016).

140. Huang, F.-L. and S.-J. Yu (2018). "Esophageal cancer: Risk factors, genetic association, and treatment." Asian journal of surgery 41(3): 210215.

141. Allum WH, Stenning SP, Bancewicz J, Clark PI, Langley RE. Long-term results of a randomized trial of surgery with or without preoperative chemotherapy in esophageal cancer. J Clin Oncol. 2009;27:5062e5067.

142. Skinner HD, Lee JH, Bhutani MS, et al. A validated miRNA profile predicts response to therapy in esophageal adenocarcinoma.Cancer. 2014;120:3635e3641.

143. Bibby BA, Reynolds JV, Maher SG. MicroRNA-330-5p as a putative modulator of neoadjuvant chemoradiotherapy sensitivity in oesophageal adenocarcinoma. PLoS One. 2015;10:e0134180.

144. Wang Y, Zhao Y, Herbst A, et al. miR-221 mediates chemoresistance of esophageal adenocarcinoma by direct targeting of DKK2 expression. Ann Surg. 2016;264:804e814.

\section{How to Cite This Article:}

Etaatifard N, Sahraei N, Ahmadifar M. Investigating the role of signaling pathways and cancer stem cells in esophageal cancer with a therapeutic approach. Mod Med Lab J. 2020; 3(1) :1-15 